\title{
DAMPAK PROFITABILITAS, ALIRAN KAS BEBAS, DAN KESEMPATAN INVESTASI TERHADAP PEMBAYARAN DIVIDEN PERUSAHAAN PERBANKAN
}

\author{
Salvatore Wika Lingga Pradana \\ I Putu Sugiartha Sanjaya \\ Departemen Akuntansi Fakultas Ekonomi Universitas Atma Jaya Yogyakarta \\ Jl. Babarsari No.43 Yogyakarta, 55281, Indonesia
}

\begin{tabular}{|c|c|}
\hline \multirow[b]{2}{*}{$\begin{array}{l}\text { Keywords: } \\
\text { Dividend, Firm Size, } \\
\text { Free Cash Flow, } \\
\text { Investment Opportu- } \\
\text { nity Set, Profitabil- } \\
\text { ity } \\
\text { JEL Classification: } \\
\text { G11, G21, G32 }\end{array}$} & Abstract \\
\hline & $\begin{array}{l}\text { This study aimed to identify and analyze the factors that affected paid dividend proxies by } \\
\text { Dividend Payout Ratio (DPR) on the banking companies listed in Indonesia Stock Exchange } \\
\text { (IDX). Multiple regression was a model of analysis that was used by the researchers to examine } \\
\text { several variables which might affect the dividend payout ratio such as profitability, free cash flow, } \\
\text { and investment opportunity set as independent variables, as well as firm size as a control variable. } \\
\text { The samples in this study were } 29 \text { conventional banks that were listed in Indonesia Stock Ex- } \\
\text { change (IDX). The result showed that the independent variable profitability (ROA) had a signifi- } \\
\text { cant and positive effect on the dividend payout ratio while the free cash flow variable and the } \\
\text { investment opportunity set did not affect the dividend payout ratio. Control variables firm size } \\
\text { had a significant and negative effect on the dividend payout ratio. }\end{array}$ \\
\hline & Abstrak \\
\hline $\begin{array}{l}\text { Kata Kunci: } \\
\text { Dividen, Ukuran } \\
\text { Perusahaan, Arus } \\
\text { Kas Bebas, Set } \\
\text { Kesempatan } \\
\text { Investasi, } \\
\text { Profitabilitas }\end{array}$ & $\begin{array}{l}\text { Penelitian ini bertujuan untuk mengidentifikasi dan menganalisis faktor-faktor yang } \\
\text { memengaruhi pembayaran dividen yang diproksikan dengan Dividend Payout Ratio (DPR) } \\
\text { pada perusahaan perbankan yang terdaftar di Bursa Efek Indonesia (BEI). Analisis Regresi } \\
\text { adalah model analisis yang digunakan oleh peneliti untuk meneliti beberapa variabel } \\
\text { yang mungkin memengaruhi DPR seperti profitabilitas, arus kas bebas, dan set } \\
\text { kesempatan investasi sebagai variabel independen, serta ukuran perusahaan sebagai } \\
\text { variabel kontrol. Sampel dalam penelitian ini adalah } 29 \text { bank konvensional yang terdaftar } \\
\text { di Bursa Efek Indonesia (BEI). Hasil penelitian menunjukkan bahwa variabel independen } \\
\text { profitabilitas (ROA) memiliki pengaruh yang signifikan dan positif terhadap rasio } \\
\text { pembayaran dividen sedangkan variabel arus kas bebas dan set kesempatan investasi } \\
\text { tidak memengaruhi rasio pembayaran dividen. Variabel kontrol ukuran perusahaan } \\
\text { memiliki pengaruh signifikan dan negatif terhadap rasio pembavaran dividen. }\end{array}$ \\
\hline
\end{tabular}


Perbankan merupakan organ vital yang penting dalam menjaga stabilitas perekonomian suatu negara. Perbankan menjalankan fungsinya berasaskan prinsip kehati-hatian (prudential banking). Karakteristik bank yang prudence menuntut bank-bank di Indonesia untuk selalu berhati-hati dalam menjalankan aktivitasnya agar tidak membahayakan nasabah atau perekonomian negara. Jika sewaktuwaktu terjadi krisis moneter, maka perbankan tetap dapat bertahan dalam menjaga stabilitas keuangan.

Ketahanan perbankan Indonesia sudah terlihat pada bulan Januari 2010. Saat itu, lembaga pemeringkat internasional, Fitch Ratings, menaikkan peringkat delapan bank di Indonesia (Bank Mandiri, Bank Rakyat Indonesia, Bank Central Asia, Bank CIMB Niaga, Bank Danamon, Bank Internasional Indonesia, Bank OCBC NISP, dan Bank UOB Buana) dari BB menjadi BB+. Kenaikan peringkat ini sesuai dengan ekspektasi Fitch Ratings bahwa perbaikan perbankan di Indonesia akan berlanjut karena prospek ekonomi makro yang lebih kuat tercipta pada tahun 2010. Kondisi tersebut berimbas pada peningkatan kualitas kredit dan profitabilitas di masa depan. Bukti itu dapat ditunjukkan dengan meningkatnya rata-rata profitabilitas bank di Indonesia dari tahun 2009 sampai 2012.

Kantor akuntan publik The Big Four, Ernst \& Young, merespon hal ini dengan mengadakan survei mengenai South East Asia Capital Confidence Barometer pada tahun 2011. Salah satu hasil survei menyatakan bahwa $71 \%$ pelaku bisnis sektor perbankan di Indonesia berencana menggunakan kelebihan uang tunai mereka untuk membayar dividen kas.

Fenomena atau realita yang terjadi sepanjang tahun 2009 sampai 2012 justru menunjukkan hasil yang berkebalikan yaitu terjadi penurunan dividend payout ratio pada bank yang membagikan dividen tunai berturut-turut. Selain itu, sebanyak 20 dari 29 bank konvensional/non-syariah yang terdaftar di BEI sepanjang tahun 2009 sampai 2012 mayoritas tidak membagikan dividen kas atau hanya satu sampai dua kali sepanjang 4 tahun. Padahal jika ditinjau dari segi profitabilitas perusahaan, mayoritas bank tersebut menunjukkan hasil yang positif.

Timbulnya fenomena tersebut diduga akibat dari peningkatan rating perbankan sendiri yang membuat Indonesia masuk ke tingkat perekonomian baru yang disebut investment grade status. Keadaan tersebut membuat industri perbankan Indonesia mempunyai kesempatan ekspansi yang tinggi agar lebih mudah dalam memperoleh akses pendanaan dari investor. Kondisi semacam ini dapat menentukan set kesempatan investasi (IOS) suatu perusahaan (Scott, 2015). Kesempatan investasi atau investment opportunity set (IOS) yang tinggi di masa depan membuat perusahaan dikatakan mempunyai tingkat pertumbuhan yang tinggi. Rozeff (1982) menyatakan bahwa tingkat pertumbuhan yang tinggi sering dikaitkan dengan penurunan dividen.

Dividen kas merupakan masalah yang sering menjadi topik pembicaraan di antara para pemegang saham dan juga pihak manajemen perusahaan emiten. Terkadang hal tersebut justru menimbulkan kontroversi antara pemegang saham dan perusahaan emiten (Hanafi, 2004). Oleh karena itu, perusahaan harus mempertimbangkan beberapa faktor dalam menentukan kebijakan dividen tunai yang optimal. Kebijakan dividen yang optimal perlu diperhatikan karena dapat menciptakan keseimbangan antara dividen saat ini dan pertumbuhan di masa depan yang memaksimumkan harga saham (Weston \& Brigham, 2005).

Berdasarkan uraian fenomena dan kontroversi tersebut, peneliti termotivasi untuk menemukan bukti-bukti empiris mengenai faktor-faktor yang memengaruhi dividend payout ratio (DPR) pada industri perbankan yang terdaftar di BEI periode 2009-2012. Faktor-faktor yang akan diteliti dalam penelitian ini yaitu Return on Assets (ROA), Free Cash Flow (FCF), dan Investment Opportunity Set (IOS). 
Hal ini disebabkan karena beberapa penelitian terdahulu melakukan penelitian pada seluruh industri seperti yang dilakukan oleh Sutrisno (2001), Suharli (2006), Suharli (2007), Pujiastuti (2008), Rosdini (2009), Mulyono (2009), serta Lucyanda \& Lilyana (2012), namun studi ini lebih khusus meneliti pada industri perbankan. Hal ini dipertimbangkan oleh peneliti karena perbankan memiliki karakteristik yang berbeda dengan perusahaan lain seperti manufaktur. Peneliti menganggap bahwa perusahaan dengan kelompok industri yang berbeda kemungkinan besar akan memiliki kebijakan dividen yang berbeda pula.

Penelitian ini bertujuan untuk mengidentifikasi dan menganalisis faktor-faktor (ROA, FCF, dan IOS) yang memengaruhi pembayaran dividen yang diproksikan dengan DPR pada perusahaan perbankan yang terdaftar di Bursa Efek Indonesia (BEI). Penelitian ini diharapkan dapat memberikan informasi yang bermanfaat dan relevan bagi para investor dalam mengambil keputusan untuk berinvestasi dalam jual beli saham sehubungan dengan ekspektasinya terhadap dividen tunai yang dibayarkan. Penelitian ini juga diharapkan dapat digunakan sebagai masukan atau tambahan wawasan serta bukti empiris mengenai pengaruh ROA, FCF, dan IOS terhadap DPR pada perusahaan perbankan yang terdaftar di BEI. Dengan demikian, penelitian ini dapat dijadikan sebagai bahan referensi bagi peneliti yang akan melakukan penelitian sejenis atau lebih lanjut.

\section{Pengembangan Hipotesis}

Menurut Jensen \& Meckling (1976), dalam kerangka hubungan keagenan (agency theory), timbulnya masalah keagenan disebabkan karena konflik kepentingan antara prinsipal dan agen, kontrak yang tidak lengkap, serta adanya asimetri informasi. Masalah keagenan yang terjadi antara investor (sebagai principal) dan manajemen (sebagai agent) tentu dapat menyebabkan timbulnya biaya keagenan (agency cost).
Di dalam penelitiannya, Mulyono (2009) mengungkapkan bahwa tingkat asimetri informasi akan cenderung relatif tinggi pada perusahaan dengan tingkat kesempatan investasi yang baik. Dalam kondisi ini, manajer memiliki informasi tentang nilai proyek di masa depan dan tindakan mereka tidak dapat diawasi secara detail oleh pemegang saham. Untuk menghalangi perilaku manajer yang buruk (opportunistic behaviour) maka pemegang saham harus bersedia mengeluarkan biaya pengawasan (monitoring cost) yang disebut agency cost atau biaya keagenan (Dewi, 2008).

Agency cost yang muncul tersebut dapat diminimalkan dengan membagi dividen kas yang menyebabkan perusahaan tidak mempunyai dana berlebih sehingga tidak bisa disalahgunakan oleh manajer. Dengan kata lain, kebijakan pembagian dividen kas dapat menjadi salah satu bentuk mekanisme pengawasan pemegang saham terhadap pihak manajemen.

Rosdini (2009) mengungkapkan kebijakan dividen sebagai suatu keputusan perusahaan apakah akan membagikan laba yang dihasilkan kepada para pemegang saham atau akan menahan laba untuk kegiatan reinvestasi dalam perusahaan. Sutrisno (2001) mengungkapkan mengenai beberapa faktor yang memengaruhi besar kecilnya dividen yang akan dibayarkan oleh perusahaan kepada pemegang saham. Faktor-faktor itu adalah sebagai berikut: (1) posisi solvabilitas perusahaan, (2) posisi likuiditas, (3) kebutuhan untuk melunasi utang, (4) rencana perluasan, (5) kesempatan investasi, (6) stabilitas pendapatan, dan (7) pengawasan terhadap perusahaan.

Dari berbagai macam faktor tersebut, studi ini mengambil 3 faktor yang akan dijadikan variabel independen dalam penelitian yaitu profitabilitas (ROA), FCF, dan IOS. Profitabilitas adalah kemampuan perusahaan dalam menghasilkan laba, sedangkan dividen merupakan sebagian dari laba perusahaan yang dapat dibagikan kepada pemegang saham. Dengan demikian, profitabilitas memiliki keterkaitan dengan DPR. 
Al-Ajmi \& Hussain (2011) bertujuan untuk menguji stabilitas kebijakan dividen dengan menguji efek aliran kas pada kebijakan dividen, mengidentifikasi faktor-faktor yang memengaruhi dividen tunai dan menguji karakteristik perusahaan yang membayar dan tidak membayar dividen. Data dikumpulkan dari Saudi-listed firms selama periode 1990-2006. Perusahaan Saudi Arabia membayar lebih rendah proporsi dividen terhadap aliran kasnya dibanding proporsi dividen terhadap laba perusahaan. Ini menujukkan laba perusahaan adalah sebagai penentu utama untuk membayar dividen. Ketika laba turun mereka dengan mudah untuk memotong atau tidak membayar dividen. Zakat juga ditemukan menjadi faktor penting dalam menjelaskan pembayaran dividen.

Studi yang dilakukan oleh Baker \& Powel (2012) dengan pengumpulan bukti secara empiris dengan metode survei bagi para manajer yang membayar dividen di Bursa Efek Indonesia. Survei ini dilakukan untuk mempelajari tentang pandangan dari para manajer tentang faktor-faktor yang memengaruhi kebijakan dividen, pengumuman dividen, dan penjelasan tentang pembayaran dividen. Pengumpulan data dilakukan dengan mail survey. Berdasarkan dari hasil survei yang dikumpulkan manajer menyatakan bahwa sangat banyak penentu dividen dibayarkan ditentukan oleh stabilitas laba dan tingkat laba sekarang dan laba masa depan.

Stabilitas laba dapat terjadi jika manajer mampu mengelola asetnya secara efektif dan efisien. Hal ini direalisasikan dengan adanya laba yang tinggi (mengacu pada ROA yang tinggi). Dengan demikian, perusahaan tersebut dianggap mampu untuk membayar sebagian porsi labanya dalam bentuk dividen tunai. Semakin tinggi laba yang mampu dihasilkan, semakin besar pula probabilitas perusahaan untuk membagikan dividen.

Ketika dalam kondisi laba yang rendah atau rugi, perusahaan tidak memiliki porsi laba yang cukup untuk dibagikan dalam bentuk dividen. Perusahaan perbankan cenderung untuk menahan laba yang ada untuk mencukupi terlebih dahulu jumlah permodalan (capital adequacy) yang diharuskan oleh Bank Indonesia. Dari uraian di tersebut, maka hipotesis yang hendak dikembangkan yaitu:

$\mathrm{H}_{1}$ : profitabilitas berpengaruh positif terhadap dividen

Aliran kas bebas (FCF) merupakan kas yang berlebih di perusahaan yang dapat dibagikan kepada para pemegang saham dalam bentuk dividen. Pembagian tersebut bisa dilakukan setelah perusahaan melakukan pembelanjaan modal (capital expenditure) seperti pembelian aset tetap secara tunai. Jensen (1986) menyatakan bahwa FCF berpengaruh positif terhadap DPR. Semakin tinggi FCF maka semakin tinggi DPR atau sebaliknya. Jensen (1986) menghubungkan FCF tersebut dengan teori keagenan (agency theory).

Chowdhury et al. (2014) menguji tentang hipotesis sinyal dan aliran kas bebas pada dividen dalam konteks emerging financial market. Penelitian ini menggunakan informasi keuangan fundamental di Chinese Companies yang terdaftar di Bursa Efek Shenzhen dan Shanghai. Para peneliti ini menguji dampak pembayaran dividen tunai pada laba masa depan dan menentukan karakteristik perusahaan-perusahaan yang membayar dividen untuk menguji hipotesis aliran kas bebas. Studi ini membuktikan bahwa perusahaan-perusahaan yang cash holdings yang tinggi, profitabilitas yang besar dan efisiensi manajerial yang tinggi sebagai penentu pembayaran dividen. Hasil ini menunjukkan bahwa hipotesis aliran kas bebas terdukung dibanding hipotesis sinyal.

Hasil ini menegaskan bahwa pemilik/pemegang saham berencana untuk membagikan dividen tunai dalam jumlah yang tinggi untuk menghindari terjadinya overinvestment (free cash flow problem) yang 
dilakukan oleh manajerial. Tindakan tersebut dilakukan untuk mengurangi agency cost pada perusahaan atau dapat dikatakan sebagai bentuk mekanisme pengawasan pemegang saham terhadap manajerial. Dari uraian tersebut, maka hipotesis yang hendak dikembangkan yaitu:

$\mathrm{H}_{2}: \quad$ aliran kas bebas berpengaruh positif terhadap dividen

Perretti et al. (2013) menguji tentang implikasi siklus hidup dan teori sinyal pada kebijakan dividen. Penelitian ini dilakukan di US stock exchange melalui American Depository Receipts. Ada beberapa variabel yang diduga dapat memengaruhi kebijakan dividen yaitu ukuran perusahaan, profitabilitas, mix of earned and contributed capital, dan kesempatan pertumbuhan. Studi ini menemukan ukuran perusahaan dan kesempatan pertumbuhan serta mix of earned and contributed capital dapat menjelaskan kebijakan dividen yang dilakukan oleh perusahaan.

Tingkat pertumbuhan perusahaan yang tinggi di masa depan biasanya diikuti dengan adanya penurunan dividen tunai. Perusahaan dengan pertumbuhan yang tinggi sering dikatakan juga memiliki kesempatan investasi tinggi. Hal ini yang memotivasi pihak manajerial untuk melakukan reinvestasi dalam jumlah besar.

Untuk semakin meningkatkan pertumbuhan tersebut, perusahaan cenderung menggunakan dana yang berasal dari sumber internal dibandingkan dengan sumber eksternal (penerbitan saham atau obligasi). Sumber dana internal lebih disukai untuk membiayai kegiatan reinvestasi karena dana tersebut memiliki risiko dan biaya yang lebih rendah. Hal ini dapat menyebabkan penurunan dividen yang akan dibagikan kepada pemegang saham. Dari uraian di atas, maka hipotesis yang hendak dikembangkan yaitu:

$\mathrm{H}_{3}$ : kesempatan investasi berpengaruh negatif terhadap dividen.

\section{METODE}

Penelitian yang dilakukan adalah penelitian empiris. Penelitian ini dilakukan dengan pengujian hipotesis untuk menemukan bukti empiris mengenai pengaruh profitabilitas (ROA), FCF, dan IOS terhadap DPR pada perusahaan perbankan yang terdaftar di BEI.

Populasi dalam penelitian ini adalah seluruh perbankan di Indonesia. Sedangkan pemilihan sampel dalam penelitian ini dilakukan berdasarkan metode purposive sampling yaitu dengan mempertimbangkan kriteria yang sesuai sehingga mendapatkan sampel yang representatif. Kriteria yang digunakan utuk memilih sampel adalah bank konvensional/non-syariah yang terdaftar di BEI sepanjang tahun pengamatan dan mempublikasikan laporan keuangan auditan. Dari hasil seleksi, peneliti memperoleh sampel sejumlah 29 bank konvensional yang terdaftar di BEI sepanjang tahun 2009 sampai 2012.

Seluruh data yang digunakan dalam penelitian ini merupakan jenis data sekunder yang diperoleh dari berbagai sumber. Peneliti memperoleh data mengenai harga saham penutupan dan jumlah dividen kas yang dibagikan dari ICMD 2012 dan 2013. Data mengenai laba bersih setelah pajak, total aset, arus kas operasi, pembelian aset tetap secara tunai, total ekuitas, dan jumlah lembar saham beredar diperoleh dari laporan keuangan auditan tahun 2009-2012 yang dipublikasikan oleh bank pada website BEI (www.idx.co.id) atau website masing-masing bank.

Dalam penelitian ini terdapat variabel dependen, variabel independen, dan variabel kontrol. Variabel dependen dalam penelitian ini adalah tingkat pembayaran dividen tunai pada perusahaan perbankan yang terdaftar di BEI diproksikan dengan dividend payout ratio (DPR). DPR dalam penelitian ini diukur berdasarkan dividen yang dibagikan per lembar saham dibandingkan dengan laba perusahaan per lembar saham. Variabel-varia- 
bel independen yang dipakai dalam penelitian ini adalah profitabilitas yang diukur dengan ROA, free cash flow yang dibagi dengan total aset dan kesempatan investasi (investment opportunity set).

Free cash flow dalam penelitian ini diukur dengan nilai bersih kenaikan/penurunan arus kas dari aktivitas operasi perusahaan (Cash Flow from Operations) yang dikurangi dengan pembelian/ investasi aset tetap secara tunai (Capital Expenditure). Peneliti kemudian membagi free cash flow dengan total assets pada periode yang sama dengan tujuan agar dapat dibandingkan antara satu perusahaan dengan perusahaan lain.

Investment Opportunity Set (IOS) akan diproksikan sebagai market to book value of equity (MVE/ BVE). Rasio ini dihitung dengan cara membagi kapitalisasi pasar (harga saham dikalikan dengan jumlah lembar saham beredar) dengan total ekuitas. Peneliti kemudian mengubah variabel IOS dengan proksi MVE/BVE menjadi variabel dummy. Hal ini dilakukan peneliti untuk menghindari efek lanjutan (domino effect) dari profitabilitas yang dikhawatirkan membuat IOS memiliki arah positif dan signifikan terhadap DPR.

Dalam penelitian ini, terdapat sebuah variabel kontrol yaitu ukuran perusahaan. Ukuran perusahaan tidak menggunakan nilai aset secara langsung karena nilai tersebut terlalu besar dan sangat berbeda jauh dengan variabel lainnya. Oleh karena itu, ukuran perusahaan menggunakan nilai logaritma natural dari total aset.

Tahapan penelitian ini meliputi uji asumsi klasik dan pengujian hipotesis. Uji asumsi klasik terdiri dari 4 pengujian, yaitu uji normalitas, uji

Tabel 1. Definisi Operasional dan Pengukuran Variabel

\begin{tabular}{|c|c|c|c|}
\hline Variabel & Definisi Operasional & Proksi & Pengukuran \\
\hline \multicolumn{4}{|l|}{ Variabel Dependen } \\
\hline \multirow[t]{2}{*}{ Dividen Tunai } & \multirow{2}{*}{$\begin{array}{l}\text { Pendistribusian laba perusahaan } \\
\text { kepada pemegang saham }\end{array}$} & \multirow[t]{2}{*}{ DPR } & \multirow{2}{*}{$\mathrm{DPR}=\frac{\text { Dividend per Share }}{\text { Earnings per Share }}$} \\
\hline & & & \\
\hline \multicolumn{4}{|l|}{ Variabel Independen } \\
\hline \multirow[t]{2}{*}{ Profitabilitas } & \multirow{2}{*}{$\begin{array}{l}\text { Efektifitas perusahaan dalam } \\
\text { menghasilkan laba bersih } \\
\text { dengan cara memanfaatkan } \\
\text { aktiva yang dimiliki }\end{array}$} & \multirow[t]{2}{*}{$\mathrm{ROA}$} & \multirow{2}{*}{$\mathrm{ROA}=\frac{\text { Net Income After Tax }}{\text { Total Assets }}$} \\
\hline & & & \\
\hline \multirow[t]{2}{*}{ Free Cash Flow } & \multirow{2}{*}{$\begin{array}{l}\text { kas yang berlebih di perusahaan } \\
\text { yang dapat dibagikan kepada } \\
\text { para pemegang saham dalam } \\
\text { bentuk dividen. }\end{array}$} & \multirow[t]{2}{*}{ FCF } & $\mathrm{FCF}=$ Cash Flow from \\
\hline & & & $\begin{array}{l}\text { Operations } \quad-\quad \text { Capital } \\
\text { Expenditure }\end{array}$ \\
\hline \multirow{2}{*}{$\begin{array}{l}\text { Investment Opportunity } \\
\text { Set }\end{array}$} & \multirow[b]{2}{*}{$\begin{array}{l}\text { Proksi kombinasi dari } \\
\text { pertumbuhan perusahaan } \\
\text { menggambarkan nilai aktiva di } \\
\text { tempat dan nilai kesempatan } \\
\text { tumbuh perusahaan dimasa } \\
\text { depan }\end{array}$} & \multirow[t]{2}{*}{ IOS } & $\mathrm{IOS}=\frac{\mathrm{MVE}}{\mathrm{DVI}}$ \\
\hline & & & $\begin{array}{l}\text { Dummy variable, MVE/BVE }>1 \text {, } \\
\text { maka diberi nilai } 1 \text { yang berarti } \\
\text { perusahaan bertumbuh. Jika rasio } \\
\text { MVE/BVE }<1 \text {, maka diberi nilai } 0 \\
\text { yang berarti perusahaan tidak } \\
\text { bertumbuh. }\end{array}$ \\
\hline \multicolumn{4}{|l|}{ Variabel Kontrol } \\
\hline Ukuran Perusahaan & $\begin{array}{l}\text { Besar suatu perusahaan } \\
\text { berdasarkan jumlah aset yang } \\
\text { dimiliki }\end{array}$ & SIZE & Size $=$ LnTotalAsset \\
\hline
\end{tabular}


Tabel 2. Deskripsi Statistik

\begin{tabular}{lrrrrr}
\hline & N & Minimum & Maximum & Mean & Std. Deviation \\
\hline ROA & 82 & $-0,0131$ & 0,0339 & 0,013939 & 0,0084276 \\
FCF & 82 & $-0,1762$ & 0,1537 & 0,005879 & 0,0671554 \\
IOS & 82 & 0,0000 & 1,0000 & 0,780488 & 0,4164634 \\
DIVIDEND & 82 & 0,0000 & 0,6956 & 0,156606 & 0,1707737 \\
SIZE & 82 & 28,0611 & 33,9444 & 31,129174 & 1,7356643 \\
Valid N (listwise) & 82 & & & & \\
\hline
\end{tabular}

multikolinearitas, uji autokorelasi, dan uji heteroskedastisitas. Uji normalitas menggunakan uji Kolmogorov-Smirnov. Uji multikolinearitas dilakukan dengan melihat nilai variance-inflating factor (VIF). Uji autokorelasi dilakukan dengan uji Durbin-Watson. Uji heteroskedastisitas dilakukan dengan uji Glejser. Untuk pengujian hipotesis dilakukan dengan regresi berganda. Model regresi berganda yang akan diteliti adalah:

$\mathrm{DPR}_{\mathrm{it}}=\beta_{0}+\beta_{1} \cdot \mathrm{ROA}_{\mathrm{it}}+\beta_{2} \cdot \mathrm{FCF}_{\mathrm{it}}+\beta_{3} \cdot \mathrm{IOS}_{\mathrm{it}}+$ $\beta_{4} \cdot \mathrm{SIZE}_{\mathrm{it}}+e$

\section{HASIL}

Pada Tabel 1 dapat dilihat hasil dari statistik deskriptif untuk variabel profitabilitas yang diproksikan dengan ROA, FCF, IOS, SIZE, dan DPR pada 82 sampel pengamatan.

Sebelum melakukan pengujian atas hipotesis, studi ini melakukan pengujian asumsi klasik seperti uji normalitas, multikolinearitas, autokorelasi, dan heteroskedastisitas. Hasil pengujian normalitas menggunakan uji Kolmogorov-Smirnov pada sampel pengamatan sejumlah 116 menghasilkan nilai Asymp. Sig. (2-tailed) sebesar 0,000, yang berarti data tidak terdistribusi normal karena lebih kecil dari 0,05.

Dalam hal demikian, proses trimming dilakukan untuk menghilangkan outlier. Setelah dilakukan trimming terhadap data outlier, jumlah sampel menjadi 82 dan dilakukan uji normalitas kembali. Pada uji Kolmogorov-Smirnov terhadap 82 sampel pengamatan menghasilkan nilai Asymp.Sig.(2-tailed) sebesar 0,133 yang menunjukkan bahwa residual terdistribusi normal karena memiliki nilai lebih besar dari 0,05. Dengan demikian, penelitian dapat dilanjutkan dengan pengujian asumsi klasik berikutnya. Hasil pengujian multikolinearitas ditunjukkan pada Tabel 3.

Tabel 3. Uji Multikolinearitas

\begin{tabular}{lcc}
\hline \multirow{2}{*}{ Model } & \multicolumn{2}{c}{ Collinearity Statistics } \\
\cline { 2 - 3 } & Tolerance & VIF \\
\hline ROA & 0,734 & 1,362 \\
FCF & 0,982 & 1,018 \\
IOS & 0,863 & 1,159 \\
SIZE & 0,718 & 1,393 \\
\hline
\end{tabular}

Variabel dependen: Dividen

Pada Tabel 3, perhitungan nilai tolerance semua variabel independen dan variabel kontrol di atas 0,5 yang berarti tidak ada korelasi antar variabel independen dengan variabel kontrol. Hasil perhitungan VIFjuga menunjukkan hal yang sama bahwa semua variabel independen dan kontrol kurang dari 5. Dengan demikian dapat disimpulkan bahwa tidak terjadi multikolinearitas antar variabel independen dengan variabel kontrol dalam model regresi.

Hasil pengujian autokorelasi menggunakan metode Durbin-Watson menghasilkan nilai sebesar 1,353. Nilai tersebut akan dibandingkan dengan nilai pada tabel DW-Test pada tingkat signifikansi $5 \%$, jumlah sampel $(\mathrm{n})=82$, dan jumlah variabel bebas sebanyak 4 . Jika dU $<\mathrm{dW}<4$-dU, maka tidak terjadi autokorelasi. Hasil menunjukkan bahwa nilai 
dW sebesar 1,353 dan tidak terletak diantara 1,7446 dan (4 - 1,7446). Dengan demikian, hasil tersebut dapat disimpulkan bahwa terjadi autokorelasi.

Studi ini menggunakan metode yang lain untuk menangani masalah autokorelasi yaitu Runs Test. Pengujian Runs ditunjukkan pada Tabel 4.

Tabel 4. Uji Autokorelasi (Runs Test)

\begin{tabular}{lc}
\hline & Unstandardized Residual \\
\hline Test Value $(\mathrm{a})$ & -.04216 \\
Cases $<$ Test Value & 41 \\
Cases $>=$ Test Value & 41 \\
Total Cases & 82 \\
Number of Runs & 36 \\
Z & -1.333 \\
Asymp. Sig. (2-tailed) & .182 \\
\hline
\end{tabular}

Hasil Runs Test memperlihatkan bahwa Asymp. Sig. (2-tailed) 0.182 lebih besar dari 0.05. Nilai yang lebih besar tersebut menunjukkan bahwa tidak terjadi masalah autokorelasi pada model regresi.

Berikut Tabel 5 merupakan hasil uji heteroskedastisitas dengan metode Glejser.

Hasil nilai signifikansi (Sig.) pada Tabel 5 menunjukkan bahwa semua variabel memiliki nilai di atas 0,05. Kesimpulan yang dapat diambil yaitu tidak terjadi gejala heteroskedastisitas pada model tersebut.

Hipotesis penelitian ini diuji dengan melakukan analisis regresi linier berganda. Analisis regresi linier berganda digunakan untuk memprediksi nilai variabel dependen atas perubahan beberapa variabel independen. Berikut ini merupakan hasil pengujian regresi berganda yang disajikan pada Tabel 6.

Berdasarkan hasil Tabel 6 dapat disusun persamaan regresi linier berganda sebagai berikut:

$$
\begin{aligned}
\mathrm{DPR}= & 0,861+9,914 \mathrm{ROA}+0,297 \mathrm{FCF}+0,000 \mathrm{IOS} \\
& -0,027 \mathrm{SIZE}+\mathrm{e}
\end{aligned}
$$

Tabel 5. Uji Heteroskedastisitas

\begin{tabular}{lccccc}
\hline \multirow{2}{*}{ Model } & \multicolumn{2}{c}{ Unstandardized Coefficients } & $\begin{array}{c}\text { Standardized } \\
\text { Coefficients }\end{array}$ & T & \multirow{2}{*}{ Sig. } \\
\cline { 2 - 4 } & $\mathrm{B}$ & Std. Error & Beta & & \\
\hline (Constant) & 0,212 & 0,208 & & 1,020 & 0,311 \\
ROA & 0,176 & 1,437 & 0,016 & 0,122 & 0,903 \\
FCF & 0,033 & 0,156 & 0,024 & 0,210 & 0,834 \\
IOS & $-0,024$ & 0,027 & $-0,107$ & $-0,882$ & 0,380 \\
SIZE & $-0,002$ & 0,007 & $-0,046$ & $-0,346$ & 0,731 \\
\hline
\end{tabular}

Dependent Variable: AbsRes

Tabel 6. Hasil Uji Analisis Regresi Berganda

\begin{tabular}{lccccc}
\hline \multirow{2}{*}{ Model } & \multicolumn{2}{c}{ Unstandardized Coefficients } & $\begin{array}{c}\text { Standardized } \\
\text { Coefficients }\end{array}$ & \multirow{2}{*}{ Sig. } \\
\cline { 2 - 4 } & $\mathrm{B}$ & Std. Error & Beta & & \\
\hline (Constant) & 0,861 & 0,347 & & 2,484 & 0,015 \\
ROA & 9,914 & 2,396 & 0,489 & 4,138 & 0,000 \\
FCF & 0,297 & 0,260 & 0,117 & 1,141 & 0,257 \\
IOS & 0,000 & 0,045 & 0,001 & 0,011 & 0,991 \\
SIZE & $-0,027$ & 0,012 & $-0,276$ & $-2,307$ & 0,024 \\
\hline
\end{tabular}

Dependent Variable: DIVIDEND 
Variabel independen profitabilitas yang diproksikan dengan ROA berpengaruh positif dan signifikan terhadap DPR. Hal ini ditunjukkan oleh nilai probabilitas signifikansi sebesar 0,000. Secara statistika, kenaikan ROA satu satuan menyebabkan angka DPR naik 9,914 satuan. Variabel independen FCF yang diukur dengan FCF/Total aset tidak berpengaruh terhadap DPR. Hal ini ditunjukkan oleh nilai probabilitas signifikansi sebesar 0,257 . Variabel independen IOS yang diproksikan dengan MVE/BVE tidak berpengaruh terhadap DPR. Hal ini ditunjukkan oleh nilai probabilitas signifikansi sebesar 0,991. Variabel kontrol SIZE yang diukur dengan LnTotalAset berpengaruh negatif dan signifikan terhadap DPR. Hal ini ditunjukkan oleh nilai probabilitas signifikansi sebesar 0,024. Secara statistika, kenaikan SIZE satu satuan menyebabkan angka DPR turun 0,027 satuan.

\section{PEMBAHASAN}

\section{Pengaruh Profitabilitas terhadap Dividen}

Hasil yang diperoleh menunjukkan bahwa variabel profitabilitas (ROA) berpengaruh positif dan signifikan terhadap dividend payout ratio pada perusahaan perbankan. Dengan kata lain, faktor profitabilitas digunakan oleh perusahaan untuk menjadi dasar pertimbangan dalam pembagian dividen tunai. Seperti yang dijelaskan dalam hipotesis pertama, profitabilitas adalah kemampuan perusahaan dalam menghasilkan laba, sedangkan dividen merupakan sebagian dari laba perusahaan yang dapat dibagikan kepada pemegang saham. Dengan demikian, hasil ini menegaskan bahwa profitabilitas memiliki keterkaitan dengan dividend payout ratio.

Perusahaan yang mampu mengelola asetnya secara efektif dan efisien cenderung menghasilkan kinerja keuangan yang baik. Hal ini direalisasikan dengan adanya laba yang tinggi. Dengan demikian, perusahaan tersebut dianggap mampu untuk membayar sebagian porsi labanya dalam bentuk dividen tunai. Semakin tinggi laba yang mampu dihasilkan, semakin besar pula probabilitas perusahaan untuk membagikan dividen.

Ketika dalam kondisi laba yang rendah atau rugi, perusahaan tidak memiliki porsi laba yang cukup untuk dibagikan dalam bentuk dividen. Perusahaan perbankan cenderung untuk menahan laba yang ada untuk mencukupi terlebih dahulu jumlah permodalan (capital adequacy) yang diharuskan oleh Bank Indonesia.

\section{Pengaruh Aliran Kas Bebas terhadap Dividen}

Hasil penelitian menunjukkan bahwa variabel aliran kas bebas tidak berpengaruh terhadap dividend payout ratio. Dalam kondisi aliran kas bebas yang tinggi, perusahaan bisa saja menahan pembagian dividen. Kemungkinan yang terjadi yaitu perusahaan perbankan memanfaatkan aliran kas bebas yang tinggi untuk menjaga kecukupan modal (capital adequacy) sesuai dengan ketentuan Bank Indonesia.

Hal ini mengacu kepada UU No. 10 Tahun 1998 tentang perubahan atas UU No. 7 Tahun 1992 tentang Perbankan. Undang-undang tersebut menetapkan bahwa bank wajib memelihara tingkat kesehatan bank dan wajib melakukan kegiatan usaha sesuai dengan prinsip kehati-hatian (prudential banking). Dengan demikian, variabel aliran kas bebas menjadi tidak signifikan dalam keputusan pembagian dividen tunai pada perbankan di Indonesia.

\section{Pengaruh Set Kesempatan Investasi terhadap Dividen}

Variabel set kesempatan investasi juga menunjukkan hasil yang tidak signifikan. Peneliti menduga bahwa terdapat faktor lain yang dapat menimbulkan dampak seperti ini. Kemungkinan faktor tersebut adalah adanya wewenang yang hampir mutlak pada RUPS. Wewenang RUPS tersebut membuat pemegang saham mayoritas atau 
pengendali memiliki posisi kuat dalam menentukan berbagai keputusan. Ketika pemegang saham mayoritas menyatakan suara atas kebijakan dividen (dividen dibagi atau ditahan), hampir dipastikan pemegang saham minoritas atau nonpengendali pada RUPS akan mengikuti keputusan tersebut. Wewenang RUPS semacam ini dapat mengakibatkan variabel IOS kurang mendapat perhatian dan menjadi tidak signifikan dalam penentuan kebijakan dividen tunai.

Di samping itu, peneliti juga menduga bahwa terjadi ekspropriasi oleh pemegang saham pengendali (controlling shareholder) sehingga dividen tunai tidak dibagi. Perusahaan dengan kepemilikan terkonsentrasi memiliki pemegang saham pengendali (controlling shareholder) yang dapat mengendalikan manajemen atau bahkan menjadi bagian dari manajemen itu sendiri.

Kondisi seperti ini dapat terjadi karena pemegang saham pengendali memiliki kontrol terhadap perusahaan melebihi hak aliran kasnya melalui mekanisme kepemilikan piramida atau lintas kepemilikan yang sering ditemui di Indonesia (La Porta et al., 1999; Claessens et al., 1999). Hal ini berpotensi menimbulkan masalah keagenan (agency conflict) yang umumnya berupa ekspropriasi melalui dividen tunai yang tidak dibagikan selama beberapa periode. Dengan demikian, variabel aliran kas bebas dan IOS menjadi tidak signifikan dalam keputusan pembagian dividen karena adanya kemungkinan ekspropriasi yang dilakukan oleh pemegang saham pengendali.

Hasil dari penelitian ini juga menunjukkan bahwa variabel kontrol ukuran perusahaan (SIZE) berpengaruh negatif dan signifikan terhadap dividend payout ratio. Peneliti berpikiran bahwa kemungkinan hal ini juga dipengaruhi adanya agency conflict yang terjadi di dalam perusahaan seperti pada kedua variabel independen sebelumnya (aliran kas bebas dan IOS). Peneliti berargumen bahwa pemegang saham pengendali termotivasi untuk menguasai harta/kekayaan perusahaan berskala besar agar memperoleh manfaat privat yang semakin besar. Pemegang saham pengendali mencoba untuk menguasai harta tersebut dengan menggunakan kontrol yang dimiliki. Hak kontrol pemegang saham pengendali yang tinggi dapat memicu timbulnya ekspropriasi dengan cara membagikan dividen dalam jumlah yang rendah atau bahkan tidak membagi dividen tunai sama sekali. Hal ini mengakibatkan pemegang saham nonpengendali tidak memperoleh manfaat secara penuh dari perusahaan berupa dividen tunai.

Argumen peneliti juga didukung oleh penelitian Siregar (2008) yang menyatakan bahwa perusahaan berukuran besar cenderung memiliki konflik keagenan yang tinggi antara pemegang saham pengendali (controlling shareholder) dengan nonpengendali. Konflik keagenan tersebut dapat memicu timbulnya ekspropriasi melalui dividen yang ditahan selama beberapa periode.

\section{SIMPULAN DAN SARAN}

\section{Simpulan}

Penelitian ini bertujuan untuk mengidentifikasi dan menganalisis faktor-faktor (ROA, FCF, dan IOS) yang memengaruhi pembayaran dividen yang diproksikan dengan DPR pada perusahaan perbankan yang terdaftar di Bursa Efek Indonesia (BEI). Hasil penelitian ini menunjukkan bahwa variabel profitabilitas berpengaruh positif dan signifikan terhadap dividend payout ratio. Peneliti menyimpulkan bahwa profitabilitas merupakan variabel utama yang masuk dalam pertimbangan RUPS untuk menentukan keputusan pembagian dividen tunai. Semakin tinggi profitabilitas (ROA), semakin besar pula probabilitas perbankan akan membagikan dividen tunai.

Sedangkan variabel free cash flow dan IOS tidak berpengaruh terhadap dividend payout ratio. Peneliti menduga bahwa terdapat faktor lain yang dapat menimbulkan dampak seperti ini. Kemungkinan faktor tersebut adalah adanya wewenang 
yang hampir mutlak pada RUPS. Di samping itu, peneliti juga menduga bahwa terjadi ekspropriasi oleh pemegang saham pengendali (controlling shareholder) sehingga dividen tunai tidak dibagi selama beberapa periode.

Beberapa keterbatasan yang ada dalam penelitian ini yaitu penelitian ini hanya menganalisis pengaruh 3 variabel independen, yaitu profitabilitas, aliran kas bebas, dan IOS terhadap dividend payout ratio. Peneliti sadar bahwa masih terdapat variabel lain yang kemungkinan besar juga ikut berperan dalam memengaruhi dividend payout ratio pada industri perbankan di Indonesia, misalnya variabel struktur kepemilikan ultimat, risiko, kebijakan utang, pajak, kecukupan modal bank (CAR), atau tingkat suku bunga. Selain itu, perusahaan yang dijadikan sampel dalam penelitian ini hanya perusahaan perbankan saja. Sampel pada perbankan relatif sedikit sehingga temuan penelitian ini tidak dapat digeneralisasikan. Waktu yang digunakan dalam penelitian ini relatif singkat yaitu hanya 4 tahun sehingga kemungkinan kurang menunjukkan kondisi/pola yang sesungguhnya.

\section{Saran}

Berdasarkan simpulan dan keterbatasan yang terdapat pada penelitian ini, ada beberapa saran yang diberikan kepada para praktisi dan para peneliti berikutnya untuk pengembangan ilmu pengetahuan. Untuk para praktisi, aliran kas bebas yang tidak dibagikan dalam bentuk dividen berpotensi untuk memunculkan konflik antara agen dan prinsipal. Aliran kas bebas seharusnya didistribusikan kepada para pemegang saham dalam bentuk dividen. Para praktisi dapat menyampaikan usulan dalam Rapat Umum Pemegang Saham ketika ada aliran kas bebas supaya dibagikan dalam bentuk dividen kepada para pemagang saham. Tujuannya adalah untuk mengurangi konflik kepentingan antara agen dan prinsipal karena konflik ini akan merugikan prinsipal atau pemilik perusahaan. Aliran kas bebas yang masih tersedia di per- usahaan akan menjadi potensi yang cukup besar bagi agen untuk mengekspropirasi kekayaan perusahaan. Hal ini menyebabkan agen akan mendapat keuntungan dan prinsipal akan menanggung kerugian. Para praktisi bisa lebih berhati-hati untuk memutuskan membeli dan menjual saham ketika dalam analisis fundamental menemukan aliran kas bebas yang masih tersimpan di perusahaan. Karena hal ini berpotensi kerugian bagi para pemegang saham karena ada kecenderungan agen akan menggunakan aliran kas bebas untuk kepentingan pribadi. Tindakan ini akan menyebabkan terjadinya penurunan nilai perusahaan. Hal ini adalah potential lost bagi investor dan potential investors.

Saran untuk pengembangan pengetahuan adalah ada variabel yang dapat memengaruhi hubungan antara aliran kas bebas dan pembagian dividen. Variabel ini muncul dari perbedaan antara hak kontrol dan hak aliran kas dari pemegang saham pengendali. Perbedaan ini sering disebut cash flow right leverage. Hal yang menarik dalam penelitian ini adalah cash flow right leverage sebagai proksi masalah keagenan dalam konteks kepemilikian perusahaan terkonsentrasi seperti di Indonesia. Cash flow right leverage tinggi mengindikasikan masalah keagenan besar antara pemegang saham pengendali dan pemegang saham non pengendali. Variabel bisa dimasukan dalam penelitian untuk menguji kembali aliran kas bebas dan dividen yang dimoderasi oleh cash flow right leverage. Hal lain untuk menunjukkan saran untuk pengembangan ilmu terkait dengan pembagian dividen adalah penggunaan teori keagenan sebagai teori yang lebih relevan untuk menjelaskan dan memprediksi pembagian dividen di Indonesia dibanding teori sinyal. Hal ini nampak jelas ketika aliran kas bebas tidak mampu memengaruhi pembayaran dividen.

Saran yang lain dapat diberikan kepada penelitian selanjutnya yaitu menggunakan beberapa variabel independen lain. Pengembangan variabel independen ini perlu dilakukan mengingat 
banyak variabel lain yang berperan dalam memengaruhi dividend payout ratio. Peneliti menyarankan agar penelitian selanjutnya mencoba untuk menggunakan variabel struktur kepemilikan ultimat karena terdapat dugaan yang mengarah pada terjadinya ekspropriasi melalui dividen yang tidak dibagi. Alasan variabel ini tidak dilakukan dalam studi ini karena data ini sangat sulit untuk diperoleh. Akan tetapi, sejak 2014 data ini mudah didapatkan dalam laporan tahunan untuk industri perbankan yang terdaftar di Bursa Efek Indonesia. Variabel kepemilikan keluarga dan non keluarga juga menjadi alternatif penting untuk diteliti bagi peneliti berikutnya. Penelitian berikutnya juga diharapkan memperluas pemilihan sampel, seperti misalnya menjadi perusahaan di sektor jasa keuangan (bank, asuransi, dan sekuritas).

\section{DAFTAR PUSTAKA}

Al-Ajmi, J., \& Hussain, H.A. 2011. Corporate Dividends Decisions: Evidence from Saudi Arabia. The Journal of Risk Finance, 12(1): 41-56.

Baker, H.K. \& Powel, G.E. 2012. Dividend Policy In Indonesia: Survey Evidence from Executives. Journal of Asia Business Studies, 6(1): 79-92.

Chowdhury, R.H., Maung, M., \& Zhang, J. 2014. Information Content of Dividends: A Case of an Emerging Financial Market. Studies in Economics and Finance, 31(3): 272-290.

Claessens, S., Djankov, S., Fan, J., \& Lang, L. 1999. Expropriation of Minority Shareholders: Evidence from East Asia. Policy Research Working Paper 2088. The World Bank.

Dewi, S.C. 2008. Pengaruh Kepemilikan Managerial, Kepemilikan Institusional, Kebijakan Hutang, Profitabilitas, dan Ukuran Perusahaan terhadap Kebijakan Dividen. Jurnal Bisnis dan Akuntansi, 10(1): 47-58.

Hanafi, M. M. 2004. Manajemen Keuangan. Yogyakarta: BPFE.

Jensen, M. \& Meckling, W. 1976. Theory of The firm: Managerial Behaviour, Agency Cost, and Ownership Structure. Journal of Financial Economics, 3: 305-306.

Jensen, M. 1986. Agency Costs of Free Cash Flow, Corporate Finance, and Takeovers. Journal American Eco- nomic Review, 76 (2): 323-329.

La Porta, R., Lopez-de-Silanes, F., \& Shleifer, A. 1999. Corporate Ownership Around the World. Journal of Finance, 54(2): 471-517.

Lucyanda, J., \& Lilyana. 2012. Pengaruh Free Cash Flow dan Struktur Kepemilikan terhadap Dividend Payout Ratio. Jurnal Dinamika Akuntansi, 4 (2): 129138.

Mulyono, B. 2009. Pengaruh Debt To Equity Ratio, Insider Ownership, Size, dan Investment Opportunity Set Terhadap Kebijakan Dividen: Studi pada Industri Manufaktur yang terdaftar di Bursa Efek Indonesia Periode Tahun 2005-2007. Tesis. Program Pasca Sarjana Universitas Diponegoro. (Tidak Dipublikasikan).

Perretti, G.F., Allen, M.T., \& Weeks, H.S. 2013. Determinants of Dividend Policies for ADR Firms. Managerial Finance, 39 (12): 1155-1168.

Pujiastuti, T. 2008. Agency Cost Terhadap Kebijakan Dividen pada Perusahaan Manufaktur dan Jasa yang Go Public di Indonesia. Jurnal Keuangan dan Perbankan, 12(2): 183-197.

Rosdini, D. 2009. Pengaruh Free Cash Flow terhadap Dividend Payout Ratio. Working Paper In Accounting and Finance, Departement of Accounting Padjajaran University.

Rozeff, M. S. 1982. Growth, Beta, and Agency Cost as Determinant of Dividend Payout Ratios. Journal Financial Research, 8: 249-259.

Scott, W.R. 2015. Financial Accounting Theory $7^{\text {th }}$ Edition. Toronto, Ontario: Pearson Education.

Siregar, B. 2008. Ekspropriasi Pemegang Saham Minoritas dalam Struktur Kepemilikan Ultimat. Jurnal Riset Akuntansi Indonesia, 11(3): 237-263.

Suharli, M. 2006. Pengaruh Profitabilitas, Leverage, dan Harga Saham terhadap Jumlah Dividen Tunai: Studi pada Perusahaan yang Terdaftar di BEI Periode 2002-2003. Jurnal Maksi, 6(2): 243-256.

Suharli, M. 2007. Pengaruh Profitability dan Investment Opportunity Set terhadap Kebijakan Dividen dengan Likuiditas sebagai Variabel Penguat. Jurnal Akuntansi dan Keuangan, Vol 9 (1): 9-17.

Sutrisno. 2001. Analisis Faktor-faktor yang Memengaruhi Dividend Payout Ratio. TEMA, II (1): 1-12.

Weston, J.F. \& Brigham, E.F. 2005. Essentials of Managerial Finance. 4th Edition. Hinsdale Illinois: The Dryden Press. 